\title{
Luteal dynamics in goats: morphological and endocrine features
}

\section{Eduardo Kenji Nunes Arashiro' ${ }^{1}$, João Henrique Moreira Viana ${ }^{2}$, Jeferson Ferreira da Fonseca $^{3}$, Luiz Sérgio de Almeida Camargo ${ }^{2}$, Carlos Antônio de Carvalho Fernandes ${ }^{4}$, Felipe Zandonadi Brandão ${ }^{1}$}

\footnotetext{
1 Universidade Federal Fluminense, Niterói, RJ, CEP: 24220-008, Brasil.

${ }^{2}$ Embrapa Gado de Leite, Juiz de Fora, MG, CEP: 36038-330, Brasil.

${ }^{3}$ Embrapa Caprinos e Ovinos, Sobral, CE, CEP: 62010-970, Brasil.

${ }^{4}$ Universidade de Alfenas, Alfenas, MG, CEP: 37130-000, Brasil.
}

ABSTRACT - The aim of this study was to establish the morphologic and endocrine characteristics of luteal dynamics in goats. It was used Toggenburg female goats that showed natural estrus in a 48-hour interval. After estrus, ultrasonographic evaluations of the ovaries were daily performed during 21 days using a portable device (5MHz probe). Blood sample was collected for plasma progresterone $\left(\mathrm{P}_{4}\right)$ determination. Corpora lutea were detected for the first time on day 5 and progressively increased in size until D9 $\left(1.26 \pm 0.08 \mathrm{~cm}^{2}\right)$, with no variation on subsequent days. In females with one ovulation, the first visualization of the corpora lutea was earlier than in those with multiple ovulation ( $4.54 \pm 0.18$ vs $5.74 \pm 0.25$ days). At the moment of the first visualization, luteal area was smaller in animals with single ovulation. Plasma $\mathrm{P}_{4}$ concentration progressively increased until day 9 and it did not show significant increase until luteolysis, characterized by a sharp decrease in $\mathrm{P}_{4}$ concentration, reaching values below $1 \mathrm{ng} / \mathrm{mL}$ in 24 hours. The luteal area slowly and gradually decreased in size. It was observed a significant positive correlation between $\mathrm{P}_{4}$ concentration and area during luteogenesis and luteolysis $(\mathrm{r}=0.63$ and $\mathrm{r}=0.50$, respectively). When corpus luteum reached its maximum size (D9), female with more than one corpora lutea, with a greater luteal tissue area, did not show $\mathrm{P}_{4}$ concentration higher than those with one ovulation (5.92 \pm 0.59 vs $7.04 \pm 0.79 \mathrm{ng} / \mathrm{mL}$ ). These results show that luteal dynamics in Toggenbur goats follow a similar pattern to those observed in other goat breeds and luteal tissue growth was positively correlated with corpora lutea functionality.

Key Words: corpus luteum, goats, progesterone, ultrasonography

\section{Dinâmica luteal em caprinos: características morfológicas e endócrinas}

RESUMO - Objetivou-se neste estudo estabelecer as características morfológicas e endócrinas da dinâmica luteal em cabras. Foram utilizadas fêmeas da raça Toggenburg que manifestaram estro natural em um intervalo de 48 horas. Após o estro, foram realizadas avaliações ultrassonográficas diárias dos ovários durante 21 dias, utilizando-se um aparelho portátil (5 MHz) Amostras de sangue foram coletadas para dosagem de progesterona $\left(\mathrm{P}_{4}\right)$ no plasma. Os corpos lúteos foram detectados pela primeira vez no D5 e aumentaram progressivamente de tamanho até o D9 $\left(1,26 \pm 0,08 \mathrm{~cm}^{2}\right)$, não havendo variação nos dias subsequentes. Nas fêmeas com uma ovulação, a primeira visualização do corpo lúteo foi mais precoce que naquelas com ovulação múltipla (4,54 $\pm 0,18$ vs 5,74 $\pm 0,25$ dias). No momento da primeira visualização, a área luteal foi menor nos animais com uma ovulação. A concentração plasmática de $\mathrm{P}_{4}$ aumentou progressivamente até o D9 e não apresentou aumento significativo até o momento da luteólise, caracterizada por uma acentuada queda da concentração de $\mathrm{P}_{4}$, atingindo valores inferiores a $1 \mathrm{ng} / \mathrm{mL}$ em um intervalo de 24 horas. A área luteal diminuiu de forma lenta e gradual. Foi observada uma correlação positiva significativa entre a área e a concentração de $\mathrm{P}_{4}$ durante a lutegêonese e a luteólise ( $\mathrm{r}=0,63$ e $\mathrm{r}=0,50$; respectivamente). No dia em que o corpo lúteo atinge sua área máxima (D9), as fêmeas com mais de um corpo lúteo, com maior área de tecido luteal, não apresentaram concentração de $\mathrm{P}_{4}$ superior à daquelas com uma ovulação $(5,92 \pm 0,59$ vs 7,04 $\pm 0,79 \mathrm{ng} / \mathrm{mL})$. Esses resultados indicam que a dinâmica luteal em caprinos da raça Toggenburg segue padrões semelhantes aos observados em outras raças e em outras espécies e que o crescimento de tecido luteal refletiu positivamente na funcionalidade do corpo lúteo.

Palavras-chave: caprinos, corpo lúteo, progesterona, ultrassonografia

\section{Introduction}

The growth of goat industry in Brazil is stimulating the use of assisted reproductive technologies for this specie.
However, the development of these techniques requires basic knowledge on ovarian physiology, which is still limited in small ruminants, especially when compared to other domestic species such as cows. 
Corpus luteum is a transitory gland responsible for sinthesys and release of progesterone $\left(\mathrm{P}_{4}\right)$, a steroidal hormone essential for early embryo development and pregnancy support (Smith et al., 1994). Correct and accurate corpus luteum identification is crucial for the success of assisted reproduction programs. Previous studies in other species reported that the presence of a functional corpus luteum positively influenced the outcome of superovulation protocols (Gonzàlez-Bulnes et al., 2002) and estrus synchronization (Brito et al., 2003; Uribe-Velásquez et al., 2010).

A positive correlation between luteal tissue area and concentration of plasma $\mathrm{P}_{4}$ was previously described for cows (Siqueira et al., 2009), sheep (Davies et al., 2006) and goats (Orita et al., 2000). In bovines, the higher number of corpus luteum is not related to an increase in concentration of plasma $\mathrm{P}_{4}$ (Mann et al., 2007). In sheep and goats, maximal plasma $\mathrm{P}_{4}$ concentration was related to the breed (Fonseca\& Torres, 2005).

In small ruminants, ovarian function was evaluated and studied mainly by surgical techniques (Camp et al., 1983). These surgical techniques, also performed in embryo transfer procedures, can not be repeatedly used because they almost always lead to some extend of adherence formation (Gonçalves et al, 2001). The use of transrectal ultrasonography in small ruminant was a hallmark in the 1990s, and important studies on ovarian physiology could be done. The ultrasonography technique allowed the identification of ovarian structures in goats with a sensitivity and specificity similar to those observed in surgical methods (Simões et al., 2005). The first sonographic studies on ovarian function, however, focused on follicular dynamics (Medan et al., 2003), and only recently, luteal activity was systematically studied in this specie (Simões et al., 2007).

The aim of this study was to characterize luteal dynamics in Toggenburg goats by ultrasonography during estrous cycle and early pregnancy, and the correlations among morphological changes in the corpus luteum and $\mathrm{P}_{4}$ plasma concentrations.

\section{Material and Methods}

The experiment was conducted during the breeding season (March and April). According to Köppen, the region climate is classified as Cwa, characterized by dry winters and rainy summers, annual temperature average from $18^{\circ} \mathrm{C}$ to $23^{\circ} \mathrm{C}$ and annual preciptation between 2000 and $2600 \mathrm{~mm}^{3}$.

In this study, twenty-three nulliparous Toggenburg goats (Capra hircus) with average age of eight months, body weight $33.5 \pm 1.2 \mathrm{~kg}$ and body condition score
$3.5 \pm 0.07$ ( 1 to 5 scale) were used. These animals did not have reproductive pathologies detectable by ultrasonography or vaginoscopy and showed estrus behavior, detected by teasers, within a 48-hour interval. After estrus detection, all females were breed twice, every day, by a sexually mature buck until the end of estrus. Fourteen goats became pregnant and two females were ruled out because of the presence of follicular cyst.

The animals were confined in coletive pens, feed with Napier grass (Pennisetum purpureum v. Taiwan) and concentrated. Water and mineral salt were provided ad libitum.

A portable ultrasound device (Aloka SSD $500^{\circledR}$, Aloka Co. Japan) equipped with an adapted $5 \mathrm{MHz}$ linear rectal transducer was used in this study. This adaptation consisted on the attachement of two hard sticks to the transducer cable. The ultrasonographic evaluations were performed always by the same technician and in the same period of the day.

Ovarian sonographic evaluations started on the day of estrus detection (Day 0) and were performed daily during 21 consecutive days. On the day of estrus detection, the single or codominant follicles were identified and measured, and evaluated until ovulation. The ovulation moment was considered as the day in which the previously identified dominant follicle was no longer present in the ovary. After ovulation, the subsequent evaluations aimed to characterize the periods of luteogenesis, luteal function and luteolisys. During these evaluations the corpus luteum area was measured on its larger diameter.

Luteal tissue area $\left(\mathrm{cm}^{2}\right)$ was considered the difference between total corpus luteum area and the luteal cavity area, when it was present. For animals with double $(n=7)$ or triple $(n=1)$ ovulation, luteal tissue area in each day of the cycle was considered as the sum of luteal tissue area from all corpus luteum present in both ovaries.

Just before each ovarian exam a blood sample was collected for further plasma $\mathrm{P}_{4}$ determination. Samples were collected by jugular vein puncture using vacuolized $5 \mathrm{~mL}$ tubes containg EDTA. Blood samples were kept in an isothermal container $\left(5^{\circ} \mathrm{C}\right)$ and they were immediately sent to the laboratory to be processed. The samples were then centrifuged at $4^{\circ} \mathrm{C}$ at $894 \mathrm{~g}$ for 20 minutes. Plasma was separated and frozen $\left(-20^{\circ} \mathrm{C}\right)$ until $\mathrm{P}_{4}$ evaluation.

The plasma $\mathrm{P}_{4}$ concentration was determined by radioimmunoassay technique (RIA) using commercial kits (Coat a Count ${ }^{\circledR}$ - DPC-Med Lab, Rio de Janeiro, Brazil) and performed at the Endocrinology laboratory of the Universidade Estadual Paulista Julio de Mesquita Filho (Unesp), Botucatu, São Paulo State, Brazil. 
Luteal tissue area and plasma $\mathrm{P}_{4}$ concentrations were checked for nomality with the Lilliefors test and for homogeneity by the Cochran and Bartlett test. The effect of post-ovulation day on luteal tissue area and plasma $\mathrm{P}_{4}$ progesterone was evaluated by analysis of variance (ANOVA), and comparisons among means determined by Tukey's test (5\% probability). The luteogenesis and luteolysis periods were characterized according to the presence of significant differences on luteal tissue area and plasma $\mathrm{P}_{4}$ concentrations. Associations among variables were determined by Pearson correlation method. Statistical analysis was performed in SAEG - Sistema de Análises Estatísticas (SAEG, 2007).

Data from all animals $(n=21)$ were used to evaluate luteogenesis, and from the nonpregnant animals $(n=7)$ to evaluate luteolysis after day 16 . To analyze luteal tissue area and $\mathrm{P}_{4}$ concentration during luteolysis, data were normalized to the moment in which plasma $\mathrm{P}_{4}$ dropped to values below $1 \mathrm{ng} / \mathrm{mL}$.

\section{Results and Discussion}

Aiming to establish the moment of the first corpus luteum detection and to track corpus luteum morphological changes along afterwards, ultrasonographic evaluations started after estrus detection. At ovulation, the mean diameter of the dominant follicle was $7.4 \pm 0.1 \mathrm{~mm}$, similar to the size previously reported on Toggenburg goats (7.7 $\pm 1.3 \mathrm{~mm}$, Maffili et al., 2006), as well as in others breeds such as Serrana (7.1 $\pm 0.1 \mathrm{~mm}$; Simões et al., 2006), Shiba (7.8 $\pm 0.2 \mathrm{~mm}$; Medan et al., 2005) and Saanen $(6.9 \pm 1.8 \mathrm{~mm}$; Maffili et al., 2005). Ultrasography is considered an efficient tool to identify ovarian structures. The sensibility and efficiency of this technique were previously demonstrated by Viñoles et al. (2004) in ewes and by Simões et al. (2005) in goats. In the present study, the mean moment of first corpus luteum visualization was Day 5 of estrous cycle (ranging from Day 4 to 7). In animals with single ovulation the first identification was performed earlier $(\mathrm{P}<0.05)$ than in animals with multiple ovulation (Table 1 ).

Dickie et al. (1999) and Viñoles et al. (2004) reported that corpus luteum identification was more difficult in sheep with multiple ovulations, which suggest that sensitivity of ultrasonographic evaluation is reduced in these cases. In the present study, the first visualization of the corpus luteum was done earlier in animals with single ovulation, although they had a smaller total luteal tissue area at this moment. On the day of the first visualization, however, luteal area was not different between animals with single or multiple ovulations when each corpus luteum was individualy considered $\left(0.56 \pm 0.06\right.$ and $0.53 \pm 0.05 \mathrm{~cm}^{2}$, respectively; $\mathrm{P}>0.05)$. Among goats with more than one ovulation ( $\mathrm{n}=8)$, only one animal had ovulations occurring in distinct ovaries. The presence of more than one corpus luteum in the same ovary may have made corpus luteum individualization more difficult, delaying identification of each corpus luteum in animals with multiple ovulations.

Previous studies demonstrated that the first visualization of the corpus luteum in goats can be performed between Day 2 and Day 3 of estrous cycle (Orita et al., 2000; Riesemberg et al., 2001; Medan et al., 2003; Simões et al., 2007) when higher frequency (7.5 MHz) transducers are used. The present study showed that corpus luteum identification can be performed with lower frequency (5 $\mathrm{MHz}$ ) transducers, which have a broader range of applications and is largely used in bovines, although first visualization was only possible two days later (on Day 5).

In small ruminants embryo transfer procedures are performed by surgical techniques at around Day-7 of estrous cycle. The use of ultrasonography prior to these surgical techniques would avoid unnecessary surgical procedures in those cases when embryo donors or recipients did not respond to the hormonal treatment, i.e., do not present a functional corpus luteum, optimizing the use of animals available and avoiding their precocious discard due to surgical consequences. Detection of corpora lutea as early as Day-5, as shown in the present study, demonstrates that ultrasonography can be performed before embryo transfer procedures to evaluate presence, number and position of corpus luteum.

After corpus luteum first detection, morphological features could be tracked in a daily basis and correlated to progesterone production, which is the main indicator of corpus luteum function. In the present study, size of luteal

Table 1 - Day and luteal tissue area $\left(\mathrm{cm}^{2}\right)$ when corpus luteum was first visualized in goats with single and multiple ovulation

\begin{tabular}{lcc}
\hline $\mathrm{N}^{\circ}$ of ovulation & Day of first visualization (days) & Luteal area at day of first visualization $\left(\mathrm{cm}^{2}\right) \dagger$ \\
\hline $1(\mathrm{n}=13)$ & $4.54 \pm 0.18 \mathrm{~b}$ & $0.56 \pm 0.06 \mathrm{~b}$ \\
$\geq 2(\mathrm{n}=08)$ & $5.74 \pm 0.25 \mathrm{a}$ & $0.83 \pm 0.11 \mathrm{a}$ \\
Mean $(\mathrm{n}=21)$ & $5.00 \pm 0.19$ & $0.63 \pm 0.07$ \\
\hline
\end{tabular}

a,b - Different letter in the same column differ $(\mathrm{P}<0.05$, ANOVA).

$\dagger$ In those animals with multiples ovulations, luteal tissue area is the sum of all corpus luteum presented in the ovaries. 
tissue area progressively increased from detection to Day 9 (growth rate of $0.16 \mathrm{~cm}^{2} /$ day, $\mathrm{P}<0.05$ ), achieving a mean size of $1.26 \pm 0.08 \mathrm{~cm}^{2}$, and entered in a plateau phase, with no significant increase on subsequent days (Fig. 1). Previous studies in goats reported that corpus luteum reached its maximum size between Day 8 and Day 11 (Camp et al., 1983; Medan et al., 2003; Simões et al., 2007), and this range may be related to differences in breed or in the technique used (surgery and ultrasonography). The morphological changes during this period were closely related to the endocrine profile. An increase on plasma $\mathrm{P}_{4}$ concentration until Day 9 was also detected (from $0.07 \pm 0.05$ to $6.31 \pm 0.46 \mathrm{ng} / \mathrm{mL}$, $\mathrm{P}<0.05$; Figure 1), and after that, no significant increase was observerd until the onset of natural luteolysis, when these concentrations began to decrease reaching values lower than $1 \mathrm{ng} / \mathrm{mL}$ in 24 hours (Figure 2).

These combined results demonstrate that luteal dynamic on Toggenburg goats was characterized by a growth phase (luteogenesis) which was associated to an increase in

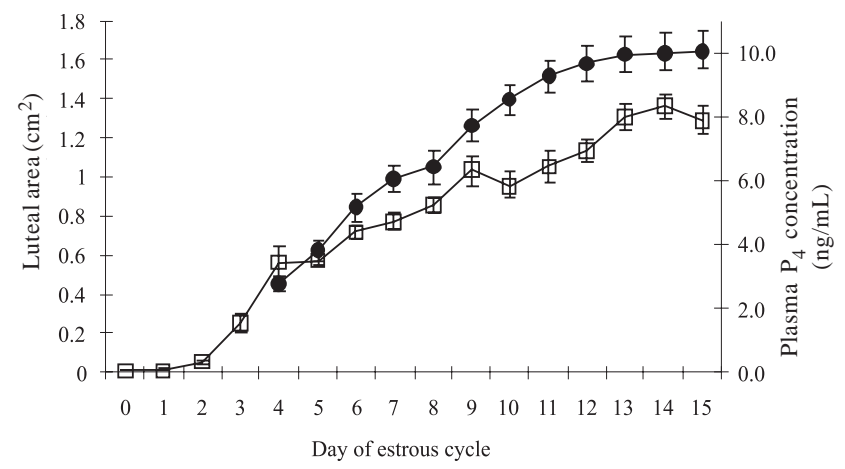

Figure 1 - Luteal tissue area $(\bullet)$ and plasma $\mathrm{P}_{4}$ concentrations $(\square)$ during luteogenesis period in Toggenburg goats (* $\mathrm{P}<0.05$ for both luteal area and plasma $\mathrm{P}_{4}$ concentration).

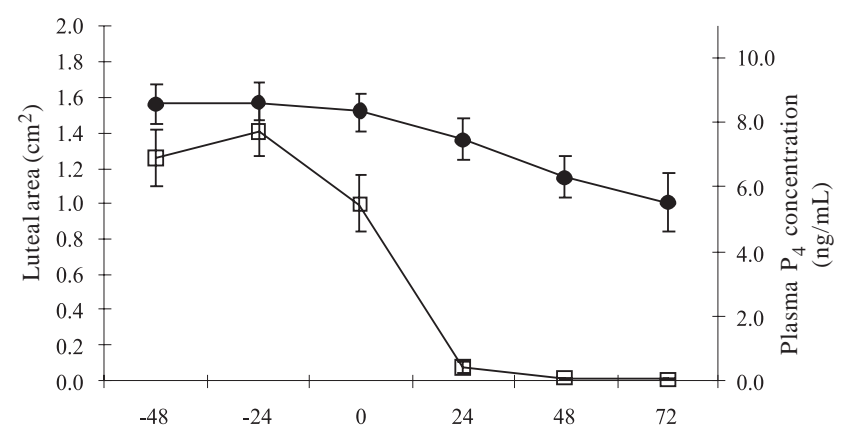

Hours in relation to luteolysis $(0=$ onset of luteolysis $)$

Figure 2 - Luteal tissue area $(\bullet)$ and plasma $\mathrm{P}_{4}$ concentrations $(\square)$ during luteolysis period in Toggenburg goats. Data were normalized to the moment of luteolysis $(* \mathrm{P}<0.05)$. corpus luteum functional maturity, as demonstrated by plasma $\mathrm{P}_{4}$ concentrations. These changes are the result of an intensive cellular proliferation and biochemical changes which occur in the corpus luteum during luteogenesis period, aiming the synthesis and release of progesterone (Smith et al., 1994; Sangha et al., 2002). The association between growth of luteal tissue and esteroidogenesis observed in the current study was similar to what was observed in other goat breeds (Orita et al., 2000; Medan et al., 2003; Simões et al., 2007), and domestic ruminants such as cows (Siqueira et al., 2009) and sheep (Davies et al., 2006). The plateau phase observed both in corpus luteum size and $\mathrm{P}_{4}$ production on day 9 , however, differs from luteal dynamics in cows, in which functional maturity is achieved after maximum corpus luteum size (Viana et al., 1999). The meaning of this difference needs further investigation, but we can hypothesize that functional maturity is attained earlier in the goat corpus luteum, based on the same earlier prostaglandin response capacity in this specie (Rubianes \& Menchaca, 2003) when compared to bovine (Weems et al., 2006).

The plateau phase was followed by a regression phase (luteolysis), characterized by a decrease both in luteal tissue area and plasma $\mathrm{P}_{4}$ concentration. The luteolysis process consists of a loss in steroidal capacity (functional luteolysis) and regression (structural luteolysis) of the corpus luteum (McCracken et al., 1999). At luteolysis, the decrease on plasma $\mathrm{P}_{4}$ concentrations ocurred faster and more abruptly when compared to the decrease observed in luteal tissue area (92 and 10\% of reduction, respectively), demonstrating the temporal difference between functional and structural luteolysis, which was also described in other goat breeds (Simões et al., 2007) and also in cows (Viana et al., 1999). This temporal difference can be explained by the fact that in the luteolysis mechanism, the very first changes induced by $\mathrm{PGF}_{2 \alpha}$ are a disruption of steroidogenic pathway activity and a reduction in availability of $\mathrm{P}_{4}$ precursors by reduction on the corpus luteum blood flow, which reduces plasma $\mathrm{P}_{4}$ concentrations to values below $1 \mathrm{ng} / \mathrm{mL}$ within 24 hours. The structural luteolysis is a more gradual process because it is mediated by an apoptotic cascade, with luteal cells death and fagocitosis, and replacement by fibroblasts (Niswender, 2000).

The difference in morphological and functional luteolysis is also reflected in the greater correlation between luteal tissue area and the progesterone found in the present study during luteogenesis $(\mathrm{r}=0.63 ; \mathrm{P}<0.05)$ when compared to luteolysis $(\mathrm{r}=0.50 ; \mathrm{P}<0.05)$. The significant overall correlation of corpus luteum morphology and function during estrous cicle was also reported in goats $(r=0.80$; 
Orita et al., 2000), cows ( $\mathrm{r}=0.69$; Siqueira et al., 2009) and sheep ( $r=0.59$; Davies et al., 2006), and it demonstrates that ultrasonography is a usefull tool to estimate luteal function in those species.

Despite the positive correlation observed between luteal tissue area and plasma $\mathrm{P}_{4}$ concentration during corpus luteum formation and regression periods, the results presented on Table 2 show that physiological capacity to synthesize and release $\mathrm{P}_{4}$ was not greater in those animals bearing more than one corpus luteum.

In cows (Mann et al., 2007) and sheeps (Bartlewski et al., 1999), an increase in plasma $\mathrm{P}_{4}$ concentrations associated with the number of ovulations was not observed either. In contrast, Jarrell \& Dziuk (1991) only detected a greater plasma $\mathrm{P}_{4}$ concentration in pregnant goats with more than one corpus luteum between Day 3 and Day 25 of estrous cycle, but after Day 30 this difference was no longer observed. This inconsistence can be related to other sources of variation in $\mathrm{P}_{4}$ production, such as breed, nutrition and body size, or even to the fluctuating nature of $\mathrm{P}_{4}$ production, which is reflected in greater variation coefficients when compared to luteal size (9.9\% vs. $3.6 \%$; respectively). In fact, on Day 9, when plasma $\mathrm{P}_{4}$ concentrations reached their maximum value, a significant correlation between luteal tissue area and plasma $\mathrm{P}_{4}$ concentration was not observed.

Luteal cavities were frequently found in the present study, being present as a central anechoic cavity in $83 \%$ of corpus luteum (25/30). On the first visualization day, the mean area of these cavities was $0.29 \pm 0.20 \mathrm{~cm}^{2}$, representing $45.3 \%$ of total area of the corpus luteum. These cavities progressively regressed in size $(\mathrm{P}<0.01)$ until Day 11 , when reached an area smaller than $0.1 \mathrm{~cm}^{2}$; representing less than $7 \%$ of total area of the corpus luteum. The luteinization of the follicle is a process that occurs from the outside to inside. When this process is not complete, a luteal cavity is formed. This cavity is a central structure filled by a clear serous transdudate (Singh et al., 1997).

Previous studies also reported a high frequency of corpus luteum with a central cavity in goats (Simões et al., 2005 -65\%; Simões et al., 2007-78\%), sheep (Dickie et al., 1999 - 12\% a 68\%; Gonzàlez-Bulnes et al., 2000 - 33.3\%), and

Table 2 - Luteal tissue area and plasma $\mathrm{P}_{4}$ concentrations when corpus luteum reached its maximum area (Day 9)

\begin{tabular}{lcc}
\hline $\begin{array}{l}\text { Number of } \\
\text { ovulation }\end{array}$ & $\begin{array}{r}\text { Luteal area on } \\
\text { day } 9\left(\mathrm{~cm}^{2}\right)^{*}\end{array}$ & $\begin{array}{r}\text { Plasma } \mathrm{P}_{4} \text { concentration } \\
\text { on day } 9(\mathrm{ng} / \mathrm{mL})\end{array}$ \\
\hline $1(\mathrm{n}=13)$ & $1.10 \pm 0.04 \mathrm{~b}$ & $5.92 \pm 0.59 \mathrm{a}$ \\
$\geq 2(\mathrm{n}=08)$ & $1.63 \pm 0.14 \mathrm{a}$ & $7.04 \pm 0.79 \mathrm{a}$ \\
\hline
\end{tabular}

a,b - Different letter in the same column differ ( $\mathrm{P}<0,05$, ANOVA).

* In those animals with multiples ovulation luteal tissua area is the sum of the area of all corpus luteum present in the ovaries. cows (Kastelic et al., 1990 - 79\%; Singh et al., $1997-72 \%$; Siqueira et al., 2009 -66\%). Despite its elevated frequency, a correlation between the presence of these cavities and duration of estrous cycle or plasma $\mathrm{P}_{4}$ concentrations was not observed; therefore corpus luteum cavities have no functional relevance (Kastelik et al., 1990, GonzalesBulnes et al., 2000). However, from a practical point of view, Viñoles et al. (2004) reported that, in early diestrus, the corpus luteum with a large central cavity can be misidentified as an ovarian follicle, delaying or even making the correct identification of the corpus luteum more difficult. Yet, as in goats, it is not possible to direct assess the reproductive tract in a non-invasive basis, the presence of an anechoic central cavity in the corpus luteum help to localize the ovaries by ultrasonography.

\section{Conclusions}

Despite of the limitations related to ultrasonographic exam in small ruminants, the identification, measurement and daily monitoring of corpus luteum can be performed by rectal ultrasonography using a $5 \mathrm{MHz}$ linear transducer; and the luteal tissue area can be used to estimate corpus luteum function, although progesterone production is not affected by the number of corpus luteum. Luteal dynamics in Toggenburg goats is characterized by a luteogenesis, a plateau and a luteolysis phase, as previously observed on other domestic ruminant species. Ultrasonography can be considered as a potential tool to evaluate corpora lutea in embryo donors and recipients.

\section{Acknowledgment}

The authors thank Dr. Eunice Oba for radioimmunoassay assistance and to Dr. Henrique Bruschi for providing the animals for the project. This study was financially supported by FAPEMIG (Project 2625-5.04/07), FOPESQ/PROPPi, FAPERJ and CAPES.

\section{References}

BARTLEWSKI, P.M.; BEARD, A.P.; RAWLINGS, N.C. An ultrasonographic study of luteal function in breeds of sheep with different ovulation rates. Theriogenology, v.52, p.115-130, 1999.

BRITO, L.F.C.; SATRAPA, R.; MARSON, E.P. et al. Efficacy of $\mathrm{PGF}_{2 \alpha}$ to synchronize estrus in water buffalo cows (Bubalus bubalis) is dependent upon plasma progesterone concetration, corpus luteum size and ovarian folicular status before treatment. Animal Reproduction Science, v.73, p.23-35, 2002.

CAMP, J.C.; WILDT, D.E.; HOWARD, P.K. et al. Ovarian activity during normal and abnormal length estrous cycles in the goat. Biology of Reproduction, v.28, p.673-681, 1983. 
DAVIES, K.L.; BARTLEWSKI, P.M.; PIERSON, R.A. et al. Computer assisted image analyses of corpora lutea in relation to peripheral concetrations of progesterone: a comparision between breeds of sheep with different ovulation rates. Animal Reproduction Science, v.96, p.165-175, 2006.

DICKIE, A.M.; PATERSON, C.; ANDERSON, J.L.M. et al. Determination of corpora lutea number in Booroola-Texel ewes using transrectal ultrasound. Theriogenology, v.51, p.1209-1224, 1999.

FONSECA, J.F.; TORRES, C.A.A. Administration of hCG 5 days after breeding and reprodictive performance in nulliparous dairy goats. Reproduction in Domestic Animals, v.40, p.495-499, 2005.

GONÇALVES, P.B.D.; FIGUEIREDO, J.R.; FREITAS, V.J.F. Biotécnicas aplicadas a reprodução animal. São Paulo: Varela Editora e Livraria Ltda, 2001. 324p.

GONZALEZ-BULNES, A.; SANTIAGO-MORENO, J.; GOMEZBRUNET, A. et al. Relationship between ultrasonographic assessment of the corpus luteum and plasma progesterone concetration during the oestrous cycle in monovular ewes. Reproduction in Domestics Animals, v.35, p.65-68, 2000.

GONZALEZ-BULNES, A.; GARCIA-GARCIA, R.M.; SANTIAGOMORENO, J. et al. Effect of follicular status on superovulatory response in ewes is influeced by presence of corpus luteum at first FSH dose. Theriogenology, v.58, p.1607-1614, 2002.

JARRELL, V.L.; DZIUK, P.J. Effect of number of corpora lutea and fetuses on concentrations of progesterone in blood of goats. Journal of Animal Science, v.69, p.770-773, 1991.

KASTELIC, J.P.; PIERSON, R.A.; GINTHER, O.J. Ultrasonic morphology of corpora lutea and central luteal cavities during the estrous cycle and early pregnancy in heifers. Theriogenology, v.34, p.487-498, 1990.

MAFFILI, V.V.; TORRES, C.A.; FONSECA, J.F. et al. Sincronização de estro em cabras da raça Saanen com esponja intravaginal e CIDR-G ${ }^{\circledR}$. Arquivo Brasileiro de Medicina Veterinária e Zootecnia, v.57 n.5, p.591-598, 2005.

MAFFILI, V.V.; TORRES, C.A.; BRUSCHI, J.H. et al. Indução do estro em cabras da raça Toggenburg com dois diferentes dispositivos intravaginais. Arquivo Brasileiro de Medicina Veterinária e Zootecnia, v.58 n.3, p.367-372, 2006.

MANN, G.E.; ROBINSON, R.S.; HUNTER, M.G. Corpus luteum size and function following single and double ovulations in nonlactating dairy cows. Theriogenology, v.67, p.1256-1261, 2007.

McCRACKEN, J.A.; CUSTER, E.E.; LAMSA, J.C. Luteolysis: a neuroendocrine-mediated event. Physiological Reviews, v.79, n.2, p.263-304, 1999.

MEDAN, M.S.; WATANABE, G.; SASAKI, K. et al. Ovarian dynamics and their associations with peripheral concnetrations of gonadotropins, ovarian steroids, and inhibin during the estrous cycle in goats. Bilogy of Reproduction, v.69, p.57-63, 2003.

MEDAN, M.S.; WATANABE, G.; SASAKI, K. et al. Follicular and hormonal dynamics during the estrous cycle in goats. Journal of Reproduction and Development, v.51 n.4, p.455-463, 2005.

ORITA, J.; TANAKA, T.; KAMOMAE, H. et al. Ultrasonographic observation of follicular and luteal dynamics during the estrous cycle in Shiba goats. Journal of Reproduction and Development, v.46, p.31-37, 2000.

RIESENBERG, S.; MEINECKE-TILLMANN, S.; MEINECKE, B. Ultrasonic survey of follicular development following superovulation with a single application of FSH, eCG or hMG in goats. Small Ruminant Research, v.40, p.83-93, 2001.

RUBIANES, E.; MENCHACA, A. The pattern and manipulation of ovarian follicular growth in goats. Animal Rreproduction Science, v.78, p.271-287, 2003.

UNIVERSIDADE FEDERAL DE VIÇOSA - UFV. SAEG - Sistema para Análise Estatística. versão 9,1. Viçosa, MG: Fundação Arthur Bernardes, 2007. 301p.

SANGHA, G.K.; SHARMA, R.K.; GURAYA, S.S. Biology of corpus luteum in small ruminants. Small Ruminant Research, v.43, p.53-64, 2002.

SIMÕES, J.; POTES, J.; AZEVEDO, J. et al. Morphometry of ovarian structures by transrectal ultrasonography in Serrana goats. Animal Reproduction Science, v.85, p.263-273, 2005.

SIMÕES, J.; ALMEIDA, J.C.; VALENTIM, R. et al. Assessment of luteal function by ultrasonographic appearance and measurement of corpora lutea in goats. Animal Reproduction Science, v.97, p.36-46, 2007.

SINGH, J.; PIERSON, R.A.; ADAMS, G.P. Ultrasound image attributes of the bovine corpus luteum: structural and functional correlates. Journal of Reproduction and Fertility, v.109, p.35-44, 1997.

SIQUEIRA, L.G.B; TORRES, C.A.A.; AMORIM, A.A. et. al. Interrelationships among morphology, echotexture and function of the bovine corpus luteum during the estrous cycle. Animal Reproduction Science, v.115, p.18-28, 2009.

SMITH, M.F.; McINTUSHI, E.W.; SMITH, G.W. Mechanism associated with corpus luteum development. Journal of Animal Science, v.72, p.1857-1872, 1994.

URIBE-VELÁSQUEZ, L.F.; SOUZA, M.I.L.; OSORIO, J.H. Resposta ovariana de cabras submetidas a implantes de progesteronas seguidos de aplicações de gonadotrofina coriônica equina. Revista Brasileira de Zootecnia, v.39, n.6, p.1214-1222, 2010.

VIANA, J.H.M.; FERREIRA, A.M.; SÁ, W.F. et al. Função luteal em vacas da raça Gir. Arquivos Brasileiros de Medicina Veterinária e Zootecnia, v.51, n.3, p.257-262, 1999.

VIÑOLES, C.; MEIKLE, A.; FORSBERG, M. Accuracy of evaluation of ovarian structures by transrectal ultrasonography in ewes. Animal Reproduction Science, v.80, p.69-79, 2004.

NISWENDER, G.D.; JUENGEL, L.J.; SILVA, P.J. et al. Mechanism controlling the function and life span of the corpus luteum. Physiological Reviews, v.80, p.1-29, 2000.

WEEMS, C.W.; WEEMS, Y.S.; RANDEL, R.D. Prostaglandins and reproduction in female farm animals. The Veterinary Journal, v.171, p.206-228, 2006 